\title{
Kinetic models assessment for swelling of coal induced by methane and carbon dioxide sorption
}

\author{
Katarzyna Czerw ${ }^{1} \cdot$ Katarzyna Zarębska $^{1} \cdot$ Bronisław Buczek $^{1} \cdot$ Paweł Baran $^{1}$
}

Received: 5 October 2015/Revised: 23 January 2016/Accepted: 28 January 2016/Published online: 5 February 2016

(C) The Author(s) 2016. This article is published with open access at Springerlink.com

\begin{abstract}
The ability of five kinetic equations to describe the sorption kinetics and expansion rate of solid coal samples was investigated. The conducted experiment included the measurements of sorption of methane and carbon dioxide on cuboidal hard coal samples at high pressure using volumetric method. Simultaneously the kinetics of coal sorption induced swelling was monitored. All of the approaches used to fit the experimental sorption and dilatometric data were literature-based equations. Two equations represent the traditional approach for sorption on powder and grain fractions based on the bidisperse gas transport model, and have been used to interpret and quantify the observed gas uptake rates in coal. The other three kinetic equations are the pseudo-second-order kinetic equation, Elovich equation, and stretched exponential (SE) equation. Four of the five equations are suitable to describe the kinetics of methane and carbon dioxide sorption in the porous structure of solid coal samples and the kinetics of coal expansion that accompany the sorption processes. The SE equation gave the best fit to the experimental data.
\end{abstract}

Keywords Hard coal - Sorption kinetics - Methane sorption $\cdot$ Carbon dioxide sorption $\cdot$ Coal swelling

Electronic supplementary material The online version of this article (doi:10.1007/s10450-016-9775-z) contains supplementary material, which is available to authorized users.

Katarzyna Czerw

kczerw@agh.edu.pl

1 Faculty of Energy and Fuels, AGH University of Science and Technology, Aleja Mickiewicza 30, 30-059 Cracow, Poland

\section{Introduction}

Ecological issues and prospective economic aspects have resulted in increasing interest in the sequestration of carbon dioxide and the enhanced coal bed methane recovery (ECBM) process, that is, recovery of methane from carboniferous deposits with simultaneous $\mathrm{CO}_{2}$ sequestration (Dutka et al. 2013; Jodłowski et al. 2007; Jodłowski 2008; Kaszuba and Janecky 2013; Wdowin et al. 2014a, b). This constitutes one method to lower the emission of carbon dioxide. Determination and clear understanding of the relations between the range of expansion/contraction of hard coal and the volume of gas sorbed in its porous structure in coal-methane, coal-carbon dioxide, and coalgas mixture $\left(\mathrm{CH}_{4}\right.$ and $\left.\mathrm{CO}_{2}\right)$ systems are important issues in carbon dioxide sequestration and recovery of methane from carboniferous formations. Fundamental issues that need to be investigated are changes caused by coal-gas $\left(\mathrm{CH}_{4}, \mathrm{CO}_{2}\right)$ interactions within a coal bed and the underlying mechanisms, as well as analytical and numerical methods to describe such changes (Czerw 2011).

Mine gases are deposited in coal beds in different forms: (1) adsorbed in micropores and on the surface of larger pores; (2) absorbed in the coal molecular structure; (3) as free gas in fissures and larger pores, which becomes significant at higher sorbate pressures; and (4) dissolved in deposit waters (Mastalerz et al. 2004; Zarębska and Ceglarska-Stefańska 2008). For the two main components of mine gas, methane has lower diffusivity, which is why its sorption rate is lower than that of carbon dioxide (Busch et al. 2004; Clarkson and Bustin 1999a, b; Cui et al. 2004). Investigation of solid hard coal samples has shown not only the sorption process, but also sorption-induced swelling of the sorbent caused by vapors and gases. Research into coal has led to the conclusion that coal is a biporous, transport- 
sorption system in which high pressure of gases causes compression of microporous regions and expansion of macropores. Expansion of microporous coal regions induced by gas sorption causes transport pores to narrow and the in situ system permeability of the bed to decrease (Pan and Connell 2007; Seewald and Klein 1986). The majority of research indicates that there is a linear relation between coal expansion and the volume of gas sorbed in its structure (Baran et al. 2015; Bustin et al. 2008; Chikatamarla et al. 2004; Cui et al. 2007; Czerw 2011; Harpalani and Chen 1995; Levine 1996; Ottinger et al. 2008; Robertson and Christiansen 2005; St. George and Barakat 2001). However, there are also studies that suggest that the sorption processes and range of contingent strains are not linearly dependent (Ceglarska-Stefanska et al. 2007; Pan and Connell 2007).

Because the majority of studies suggest that the swelling of coal is approximately proportional to the volume of sorbed gas, herein we assume that it might be possible to use the same approach to determine equations that provide a mathematical description of the kinetic curves for both sorption and swelling. Sorption kinetics concerns the time dependence or rate of reactions, and it is usually described in terms of a mathematical relationship between the amount of sorbed substance (equivalent to weight gain or volume of accumulated agent) and time. Unipore and bidisperse gas transport models have been used to interpret and quantify the observed gas uptake rates in coal with equations of different complexity (Busch and Gensterblum 2011). The unipore model is based on the solution to Fick's second law for spherical symmetric flow. It should be noted that the model assumes spherical homogeneous coal particles with the same radius and a smooth surface, a homogeneous pore structure, isothermal conditions, and that the diffusion coefficient is independent of the concentration and location in the coal particle (Busch et al. 2004; Charrière et al. 2010; Clarkson and Bustin 1999b; Pan et al. 2010; Pone et al. 2009). Ruckenstein et al. (1971) developed a bidisperse sorption/diffusion model that can be used for coals characterized by two distinct pore systems. The model defines these systems as an agglomeration of many microporous spheres contained in macropores. The model assumes a linear isotherm in both macro- and microspheres and a step change in the boundary concentration at the start of a sorption step (Busch et al. 2004; Clarkson and Bustin 1999b; Cui et al. 2004; Siemons et al. 2007; Shi and Durucan 2003a, b; Yi et al. 2008). However, $\mathrm{CO}_{2}$ and $\mathrm{CH}_{4}$ sorption isotherms are typically non-linear for natural coal, which limits the applicability of the model (Busch and Gensterblum 2011). Although it is not generally confirmed, unipore models seem to better represent the sorption kinetics of high rank coals (medium-volatile bituminous coal to anthracite) while bidisperse models better represent low rank coals. This is in agreement with the observation that micropores increase and mesopores decrease with coal rank (Busch and Gensterblum 2011).

In this study, we evaluated the ability of a variety of sorption kinetics equations to describe not only the sorption kinetics but also the rate of expansion/contraction of hard coal in coal-carbon dioxide and coal-methane systems.

\section{Experimental methods}

The sorption of methane and carbon dioxide on cuboidal hard coal samples was investigated at high pressure. Basic coal samples (high-volatile bituminous $\mathrm{C}$ rank according to ECE-UN In Seam Coal Classification, type 32.2 according to Polish standard PN-82/G-97002) were obtained from the Brzeszcze-Silesia mine. A coal sample with dimensions of $20 \mathrm{~mm} \times 20 \mathrm{~mm} \times 40 \mathrm{~mm}$ was cut out of the basic coal in such a way that the $20 \mathrm{~mm} \times 20 \mathrm{~mm}$ walls were parallel to the bedding plane. The results of analysis performed on the basic coal samples are shown in Table 1 . The two coal samples are designated $\mathrm{CH}_{4}$ and $\mathrm{CO}_{2}$ according to the gas used in the sorption experiment.

At the same time as the sorption kinetics were monitored, changes of the sample's overall dimensions accompanying the sorption processes were measured. Experiments were performed using the apparatus and test procedures described by Majewska and Ceglarska-Stefanska (2009). The experimental set-up consisted of two individual units: (1) a gas sorption apparatus using the volumetric method (pressure meter MKS BARATRON 722A with a measuring range of $0-4.0 \mathrm{MPa}$ and measurement accuracy $\pm 0.001 \mathrm{MPa}$ ) and (2) a strain meter to measure changes in the external dimensions of the samples induced by gas sorption and pressure (electrical resistance bridge, type SGM-1C81, constructed in the Strata Mechanics Research Institute of The Polish Academy of Science, measuring the range of linear strain $\sim 4 \%$, measurement accuracy $0.001 \%$, with domestic production resistance-type paper strain gauge type RL120) (Fig. 1). The whole apparatus was thermostabilized, which enabled measurements to be taken at a constant temperature of $298 \mathrm{~K}$. The experimental procedure included degassing of the sorption apparatus and sample (vacuum $\left.10^{-5} \mathrm{~Pa}\right)$ and immersion in a helium bath $(10 \mathrm{kPa})$. This was performed to remove possible interfering sorbed gases and vapors, including water, from the porous coal structure. The kinetics of methane and carbon dioxide sorption were determined from the results of the experiments based on the pressure changes in the sample cell. The kinetics of the induced strain perpendicular $\left(\varepsilon_{\mathrm{T}}\right)$ and parallel $\left(\varepsilon_{\mathrm{L}}\right)$ to the bedding plane were calculated, from which the kinetics of the volumetric strain $\left(\varepsilon_{\mathrm{V}}\right)$ was calculated using the equation $\varepsilon_{\mathrm{V}}=\varepsilon_{\mathrm{T}}+2 \varepsilon_{\mathrm{L}}$. 
Table 1 Specification of coal samples: proximate and ultimate analysis, maceral composition, mineral matter content, and vitrinite reflectance $\left(\mathrm{CH}_{4}\right.$ : Czerw et al. 2010; $\mathrm{CO}_{2}$ : Czerw 2011)

\begin{tabular}{|c|c|c|c|c|c|c|c|c|c|c|c|c|c|c|}
\hline Coal* & $\mathrm{W}^{\mathrm{a}}(\%)$ & $\mathrm{A}^{\mathrm{a}}(\%)$ & $\mathrm{C}^{\mathrm{a}}(\%)$ & $\mathrm{C}^{\mathrm{daf}}(\%)$ & \multicolumn{2}{|c|}{$\mathrm{H}^{\mathrm{a}}(\%)$} & $\mathrm{N}^{\mathrm{a}}(\%)$ & \multicolumn{2}{|c|}{$\mathrm{S}^{\mathrm{a}}(\%)$} & \multicolumn{2}{|c|}{$\mathrm{R}^{\mathrm{o}}(\%)$} & \multicolumn{2}{|c|}{$\mathrm{d}_{\mathrm{R}} 10^{3}\left(\mathrm{~kg} / \mathrm{m}^{3}\right)$} & $\mathrm{d}_{\mathrm{A}} 10^{3}\left(\mathrm{~kg} / \mathrm{m}^{3}\right)$ \\
\hline \multicolumn{15}{|c|}{ Proximate and ultimate analysis } \\
\hline $\mathrm{CH}_{4}$ & 2.3 & 4.09 & 77.53 & 82.82 & 4.56 & & 1.43 & & 0.22 & & 77 & 1.345 & & 1.311 \\
\hline $\mathrm{CO}_{2}$ & 1.52 & 11.23 & 72.21 & 82.76 & 4.31 & & 1.19 & & 0.37 & & 78 & 1.379 & & 1.355 \\
\hline Coal* & $\begin{array}{l}\text { Telinite } \\
(\%)\end{array}$ & $\begin{array}{l}\text { Collotelinite } \\
(\%)\end{array}$ & $\begin{array}{l}\text { Vitrodetrinit } \\
(\%)\end{array}$ & $\begin{array}{l}\text { ite Collodet } \\
(\%)\end{array}$ & inite & $\begin{array}{l}\text { Corp } \\
(\%)\end{array}$ & gelinite & $\begin{array}{l}\text { Geli } \\
(\%)\end{array}$ & linite & $\begin{array}{l}\text { Total } \\
\text { vitrin }\end{array}$ & ite $(\%)$ & $\begin{array}{l}\text { Sporinite } \\
(\%)\end{array}$ & $\begin{array}{l}\text { Resinite } \\
(\%)\end{array}$ & $\begin{array}{l}\text { Liptodetrinite } \\
(\%)\end{array}$ \\
\hline \multicolumn{15}{|c|}{ Coal macerals and mineral matter content } \\
\hline $\mathrm{CH}_{4}$ & 2.8 & 33.7 & 0.3 & 9.6 & & 0.3 & & 1.7 & & 48.4 & & 7.8 & 0.5 & 1.6 \\
\hline $\mathrm{CO}_{2}$ & 3.0 & 24.2 & 1.3 & 9.2 & & 1.0 & & 2.5 & & 41.2 & & 6.5 & 2.1 & 2.3 \\
\hline Coal* & $\begin{array}{l}\text { Cutinite } \\
(\%)\end{array}$ & $\begin{array}{l}\text { Total } \\
\text { liptinite } \\
(\%)\end{array}$ & $\begin{array}{l}\text { Fusinite } \\
(\%)\end{array}$ & $\begin{array}{l}\text { Semifusinite } \\
(\%)\end{array}$ & $\begin{array}{l}\mathrm{Mac} \\
(\%)\end{array}$ & rinite & $\begin{array}{l}\text { Micrini } \\
(\%)\end{array}$ & & $\begin{array}{l}\text { Fungil } \\
(\%)\end{array}$ & & $\begin{array}{l}\text { Inertode } \\
(\%)\end{array}$ & trinite & $\begin{array}{l}\text { otal } \\
\text { lertinite } \\
\text { o) }\end{array}$ & $\begin{array}{l}\text { Mineral } \\
\text { matter }(\%)\end{array}$ \\
\hline
\end{tabular}

Coal macerals and mineral matter content

$\begin{array}{lllllllllll}\mathrm{CH}_{4} & 0 & 9.9 & 15.8 & 11.2 & 1.1 & 0.9 & 0.2 & 8.4 & 37.6 & 4.1 \\ \mathrm{CO}_{2} & 0 & 10.9 & 14.2 & 18.6 & 2.6 & 1.2 & \text { śl. } & 8.4 & 45.0 & 2.9\end{array}$

$W^{a}$ moisture content, $A^{a}$ ash content, $C^{a}$ content of element $\mathrm{C}$, air-dried basis, $C^{\text {daf }}$ content of element C, dry-ash-free basis, $H^{a}$ content of element $\mathrm{H}$, air-dried basis, $N^{a}$ content of element $\mathrm{N}$, air-dried basis, $S^{a}$ content of element $\mathrm{S}$, air-dried basis, $R^{o}$ vitrinite reflectance, $d_{R}$ true density, $d_{A}$ apparent density

* The names of the samples correspond to the gas used in the sorption experiments

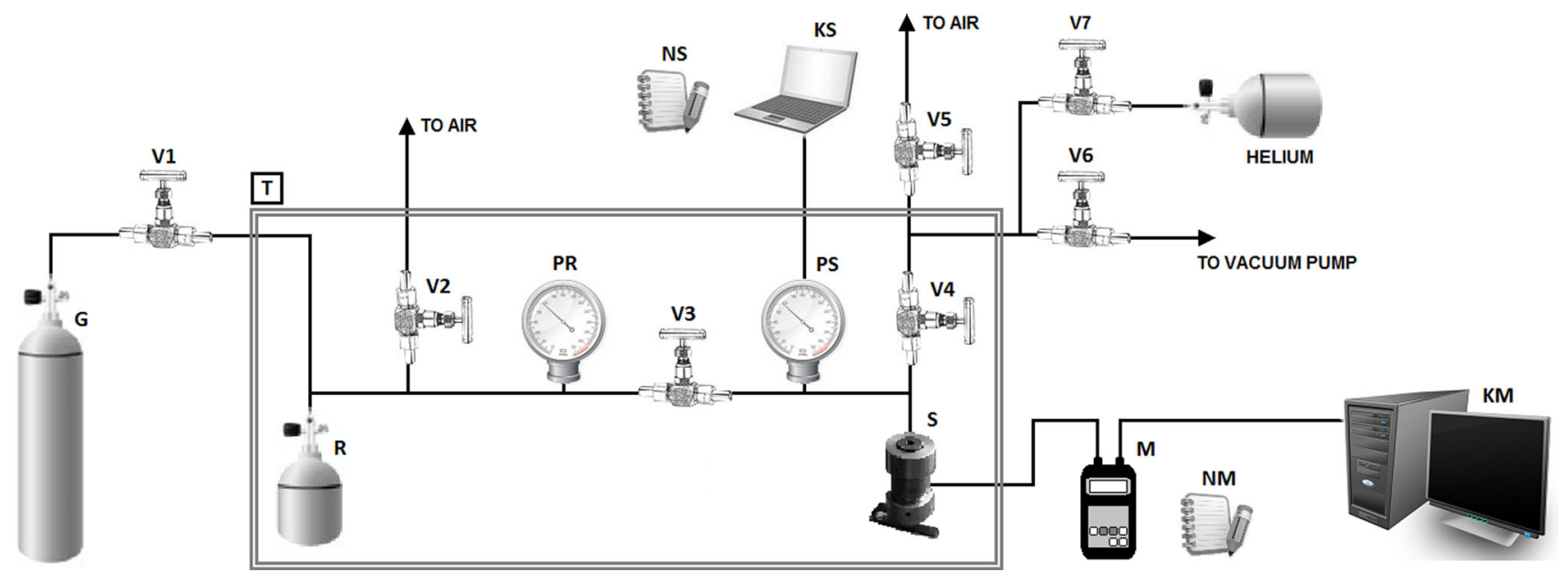

Fig. 1 Schematic diagram of the experimental setup. $G$ gas supply cylinder, $R$ reference cell, $S$ sample cell, $M$ strain meter, $T$ temperature-controlled environment, $P S, P R$ pressure transducers, $V 1, V 2$,

\section{Results}

Figure 2 shows the kinetic curves of sorption of carbon dioxide and methane in the porous structure of the coal samples and the kinetic curves of coal expansion that accompany the sorption processes. The $x$ axis represents
$V 3, V 4, V 5, V 6, V 7$ pressure valves, $K S, K M$ PC-based data recording units, $N S, N M$ hand-written data records

the time of contact between the sample and the sorbate [Time (h)].The $y$ axis shows the volumetric swelling of coal [Swelling $(\%)$ ], which corresponds to the amount of gas (centimeter cubed at Normal Temperature and Pressure conditions per gram) sorbed in the porous coal structure [Sorption $\left.\left(\mathrm{NTPcm}^{3} / \mathrm{g}\right)\right]$. 


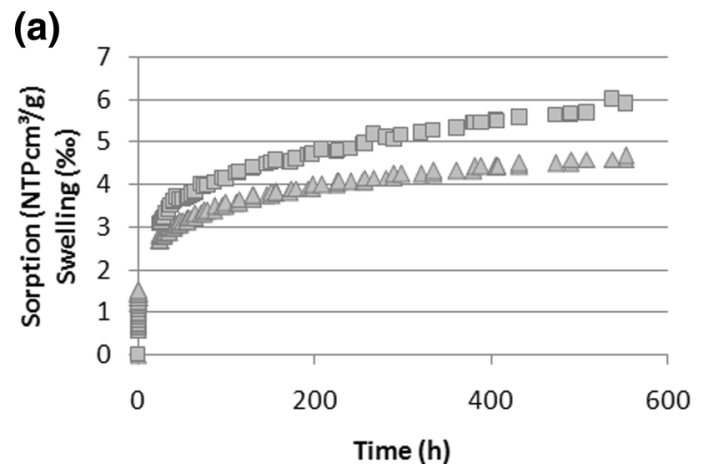

Fig. 2 Kinetics of gas sorption and swelling for $\mathbf{a} \mathrm{CH}_{4}$ (Czerw et al. 2010) and b $\mathrm{CO}_{2}$. The experimental data are given symbols corresponding to the gas and the process that they represent: triangle

\section{Discussion}

\subsection{Carbon dioxide and methane sorption kinetics}

Five sorption kinetic equations were investigated. The approach of Busch et al. (2004) is based on the bidisperse sorption/diffusion model and describes the gas sorption kinetics as a linear combination of two first-order rate functions:

$Y_{\text {residual }}(t)=Y^{\prime} \exp \left(-k^{\prime} t\right)+Y^{\prime \prime} \exp \left(-k^{\prime \prime} t\right)$

The normalized equilibration curves are expressed in terms of the relative residual (unoccupied) sorption amount $Y_{\text {residual }}\left(Y_{\text {res }}\right)$ as a function of time with different rate constants $k^{\prime}$ and $k^{\prime \prime}$, and normalized sorption at equilibrium $Y^{\prime}$ and $Y^{\prime \prime}$ (with $Y^{\prime \prime}=1-Y^{\prime}$ ) because the authors classify the transport as fast and slow. In contrast to the unipore model, this equation provides a perfect fit of the experimental data using a simple semi-empirical approach (Busch et al. 2004).

The expansion kinetics can be described by the equation:

$E_{\text {residual }}(t)=E^{\prime} \exp \left(-k^{\prime} t\right)+E^{\prime \prime} \exp \left(-k^{\prime \prime} t\right)$

where $E_{\text {residual }}\left(E_{\text {res }}\right)$ is the relative residual expansion, which is the potential relative swelling described by $E_{\text {res }}(t)=\left[E(t)-E_{\text {eq }}\right] /\left(E_{0}-E_{\text {eq }}\right), k^{\prime}$ and $k^{\prime \prime}$ are different rate constants, and the parameters $E^{\prime}$ and $E^{\prime \prime}$ represent expansion at equilibrium (with $E^{\prime \prime}=1-E^{\prime}$ ). For the purpose of this analysis, the values of the equilibrium sorption amount $\left[V_{\mathrm{eq}}\left(\mathrm{NTP} \mathrm{cm}^{3} / \mathrm{g}\right)\right]$ and equilibrium expansion $\left[E_{\text {eq }}(\%)\right]$ were calculated.

Following the approach of Siemons et al. (2007), an equation based on the bidisperse sorption/diffusion model composed of the sum of two exponentially decreasing functions was used. This procedure is similar to that presented by Busch et al. (2004) and includes splitting the

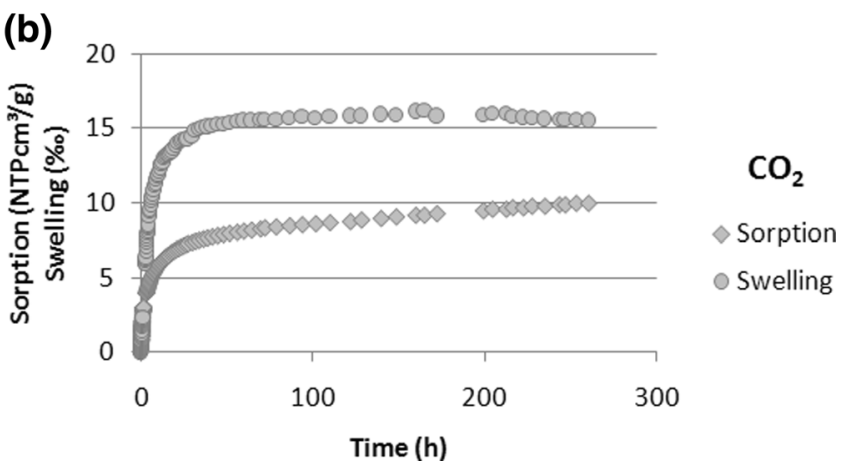

for $\mathrm{CH}_{4}$ sorption, diamond for $\mathrm{CO}_{2}$ sorption, square for $\mathrm{CH}_{4}$-sorptioninduced swelling, and circle for $\mathrm{CO}_{2}$-sorption-induced swelling

sorption contributions into a fast and a slow process to give the double-exponential (DE) equation:

$\left(\frac{P}{Z}\right)(t)=A^{\prime} \exp \left(-\frac{t}{t^{\prime}}\right)+A^{\prime \prime} \exp \left(-\frac{t}{t^{\prime \prime}}\right)+P_{e q}$

The changes of pressure $P$ divided by compressibility factor $Z(P / Z)$ are a measure of the sorption progress. The pressure decay curves are characterized by the intensities $A^{\prime}$ and $A^{\prime \prime}$ (with $A^{\prime \prime}=\left(P_{0}-P_{\text {eq }}\right)-A^{\prime}$ ) and two characteristic times: $t^{\prime}$ for the fast process and $t^{\prime \prime}$ for the slow process. $P_{\text {eq }}$ is the pressure offset of the individual pressure step (equilibrium pressure) and $t(\mathrm{~h})$ represents the experimental time. The equation for the expansion kinetics is:

$E_{\text {remaining }}(t)=A^{\prime} \exp \left(-\frac{t}{t^{\prime}}\right)+A^{\prime \prime} \exp \left(-\frac{t}{t^{\prime \prime}}\right)+E_{\text {eq }}$

where $E_{\text {remaining }}$ is the remaining potential expansion, $E_{\text {remaining }}=E_{\text {eq }}-E(t)$, and $A^{\prime \prime}=\left(E_{0}-E_{\text {eq }}\right)-A^{\prime} . \mathrm{A}$ similar equation was developed by Gawor and Skoczylas (2014), although the equation is based on the heat conductivity equation and involves measurements of the heat balance of a coal-coated thermometer during the gas sorption process.

Marecka and Mianowski (1993) proposed an empirical kinetic pseudo-second-order rate equation (PSOE) under isothermal-isobaric conditions based on chemometric analysis of kinetic equations describing the diffusion process in the hard coal-gas system. The mathematical form of the PSOE was first proposed by Blanchard et al. (1984) to describe the kinetics of heavy metal removal by natural zeolites. It is the most commonly used equation to describe sorption kinetic data (Płaziński et al. 2013; Marczewski et al. 2013). The general form of the differential equation describing the rate of fractional uptake given by Marecka and Mianowski (1993) is:

$\frac{d y}{d t}=k\left(\frac{y_{\infty}-y}{y_{\infty}}\right)^{2}$ 
The equation is characterized by two parameters: the kinetic constant $k$ as the rate constant of the sorption process and the parameter $y_{\infty}$, which is a measure of the distance from the state of sorption equilibrium and is called the limit parameter. For the initial conditions $t=0$ and $y=0$, Eq. (5) leads to:

$y=y_{\infty} \frac{k t}{y_{\infty}+k t}$

where $y$ is the sorption progress $y=a / a_{\text {eq }}$. The authors showed that application of the proposed equation for the description of the kinetics of $\mathrm{CO}_{2}$ and $\mathrm{CH}_{4}$ sorption on coal was justified. For the purpose of this analysis, Eq. (6) was transformed to Eqs. (7) and (8) to include the sorption amount rate and swelling rate:

$V(t)=V_{e q} \frac{k t}{1+A k t}$

$E(t)=E_{e q} \frac{k t}{1+A k t}$

where parameter $A$ is substituted for $1 / y_{\infty}$. The values of the equilibrium sorption amount $\left[V_{\mathrm{eq}}\left(\mathrm{NTPcm}^{3} / \mathrm{g}\right)\right]$ and equilibrium expansion $\left[E_{\text {eq }}(\%)\right]$ have been previously calculated.

The Elovich equation (Aharoni and Suzin 1982; Aharoni and Tompkins 1970) corresponds to chemisorption. Because the sorbed amount has no maximum value it goes to infinity and should be avoided. However, it was adapted for the purpose of this analysis in its integrated forms:

$V(t)=\frac{1}{B} \ln (A B t+1)$

$E(t)=\frac{1}{B} \ln (A B t+1)$

These equations are characterized by the two parameters $A$ and $B$.

The stretched exponential (SE) equation was developed as a global kinetic equation by Kolmogorov, Erofeev, Kozeeva, Avrami, and Mampel, and it is called the KEKAM equation (Avrami 1939; Brouers and SotolongoCosta 2006). For the purpose of this analysis, the following forms were used:

$V(t)=V_{e q}\left\{1-\exp \left[-(k t)^{A}\right]\right\}$

$E(t)=E_{e q}\left\{1-\exp \left[-(k t)^{A}\right]\right\}$

which are characterized by parameter $A$ and rate coefficient $k$. The values of the equilibrium sorption amount $\left[V_{\mathrm{eq}}\right.$ $(\mathrm{NTPcm} / \mathrm{g})]$ and equilibrium expansion $\left[E_{\text {eq }}(\%)\right]$ have been previously calculated.

\subsection{Analysis results}

Figures 3, 4, 5, 6, and 7 show scatterplots of the application of the kinetic equations. Additional Figs. S1-S5, analogues to Figs. 3, 4, 5, 6, and 7, are given in Online Resource 1. In Figs. S1-S5 $t^{1 / 2}$ time scale was used instead of linear time scale.

The first approach using the equation of Busch et al. based on two combined first-order rate functions gives a reasonable fit to the experimental data for $\mathrm{CH}_{4}$ and $\mathrm{CO}_{2}$ sorption and swelling, but the approximation seems to be better in the case of the expansion measurements (Fig. 3). The residual (unoccupied) relative sorption amount $\left(Y_{\text {residual }}\right)$ (Fig. 3a, b) or the amount of residual expansion $\left(E_{\text {residual }}\right)($ Fig. 3c, d) is shown on the $y$ axis and the $x$ axis is time $(\mathrm{h})$.

The equation proposed by Siemons et al. (2007) is the relationship between the pressure [P/Z (MPa)] (Fig. 4a and b) or the amount of remaining expansion $\left(E_{\text {remaining }}\right)$ (Fig. 4c, d) and time (h). Figure 4 shows that the pressure decay curves for both $\mathrm{CH}_{4}$ and $\mathrm{CO}_{2}$ sorption and the swelling behavior are well-fitted by the Siemons equation, and the fit is better than for the Busch equation (Fig. 3). However, the difference between the experimental data and the fitted results for the swelling behavior with $\mathrm{CO}_{2}$ after about $200 \mathrm{~h}$ makes this equation inadequate (Fig. 4d).

The fitting results of the PSOE, Elovitch equation, and SE are shown in Figs. 5, 6, and 7, respectively. In these figures, the $y$ axis is the amount of sorbed gas [Sorption $(\mathrm{NTPcm} / \mathrm{g})]$ for parts $\mathrm{a}$ and $\mathrm{b}$, and the volumetric swelling of coal [Swelling (\%o)] for parts $\mathrm{c}$ and $\mathrm{d}$. The $x$ axis is time (h).

The PSOE shows good agreement with the experimental data obtained by Marecka and Mianowski (1993). However, application of the proposed equation to the experimental data of sorption of $\mathrm{CH}_{4}$ and $\mathrm{CO}_{2}$ is unsuitable (Fig. 5a, b), it is not suitable for the swelling kinetics (Fig. 5c, d). We calculated the equilibrium sorption amount $\left[V_{\text {eq }}\left(\mathrm{NTPcm}^{3} / \mathrm{g}\right)\right]$ and equilibrium expansion $\left[E_{\text {eq }}(\%)\right]$. However, the kinetic PSOE underestimates these values. The conclusion is that the PSOE might be unsuitable for experiments with solid samples, in contrast to traditional research of sorption on powders and grain fractions.

From Fig. 6, the Elovitch equation is able to accurately describe the sorption kinetic of $\mathrm{CH}_{4}$ and $\mathrm{CO}_{2}$ as well as the $\mathrm{CH}_{4}$-induced swelling behavior of coal (Fig. 6a-c). This equation shows good agreement with experimental data, except for the $\mathrm{CO}_{2}$-induced swelling behavior (Fig. 6d).

Figure 7 shows the results of applying the SE kinetic equation. The fitted results are in excellent agreement with the test results. This equation is the most promising 

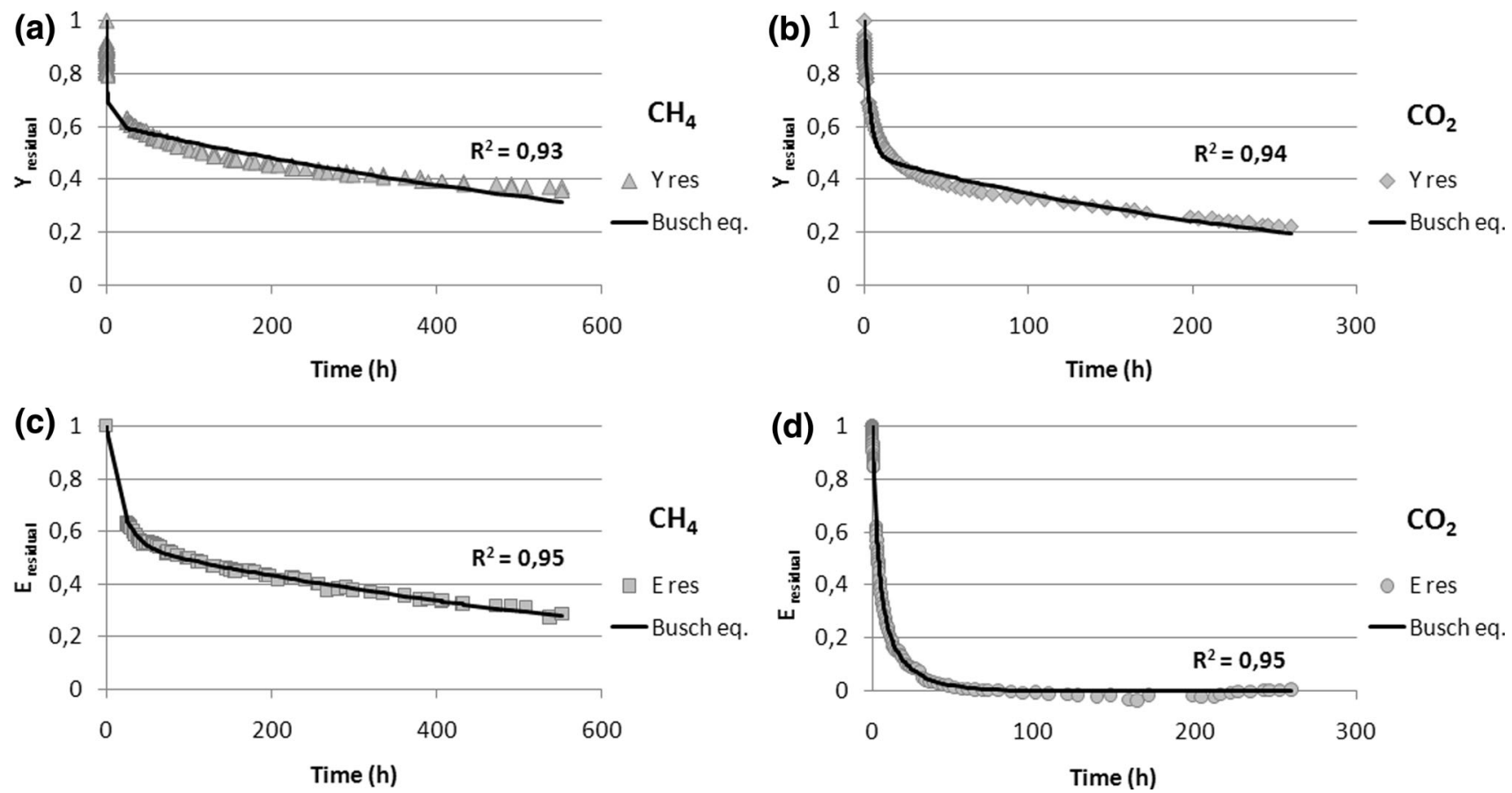

Fig. 3 Application of the Busch equations to the kinetics for a $\mathrm{CH}_{4}$ and $\mathbf{b} \mathrm{CO}_{2}$ sorption (Eq. 1), and the sorption-induced coal swelling kinetics for $\mathbf{c} \mathrm{CH}_{4}$ and $\mathbf{d} \mathrm{CO}_{2}$ (Eq. 2). The residual values are given symbols: triangle for $\mathrm{CH}_{4}$ sorption, diamond for $\mathrm{CO}_{2}$ sorption, square

for $\mathrm{CH}_{4}$-sorption-induced swelling, and circle for $\mathrm{CO}_{2}$-sorptioninduced swelling. The solid line corresponds to the results of Busch equation application

(a)

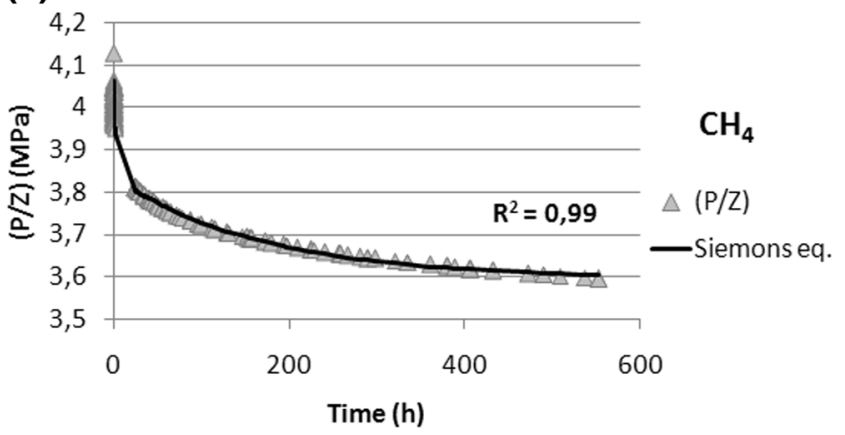

(c)

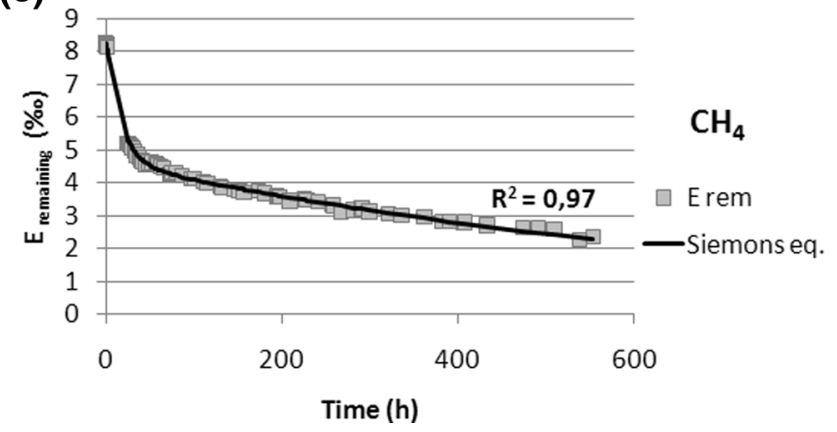

Fig. 4 Application of the Siemons equations to the kinetics for $\mathbf{a} \mathrm{CH}_{4}$ and $\mathbf{b} \mathrm{CO}_{2}$ sorption (Eq. 3), and the sorption-induced coal swelling kinetics for $\mathbf{c} \mathrm{CH}_{4}$ and $\mathbf{d} \mathrm{CO}_{2}$ (Eq. 4). The remaining values are given symbols: triangle for $\mathrm{CH}_{4}$ sorption, diamond for $\mathrm{CO}_{2}$ sorption, square (b)

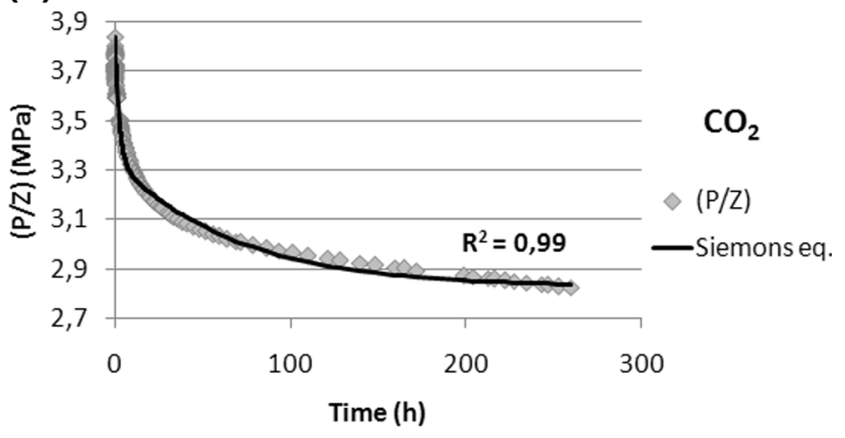

(d)

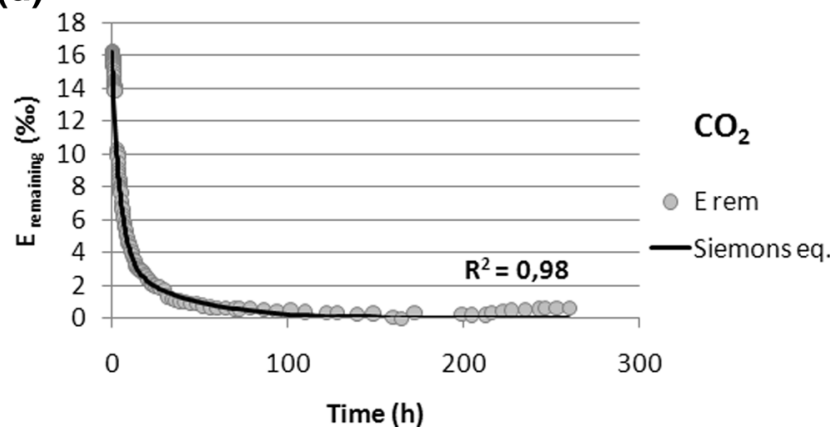

for $\mathrm{CH}_{4}$-sorption-induced swelling, and circle for $\mathrm{CO}_{2}$-sorptioninduced swelling. The solid line corresponds to the results of Siemons equation application 

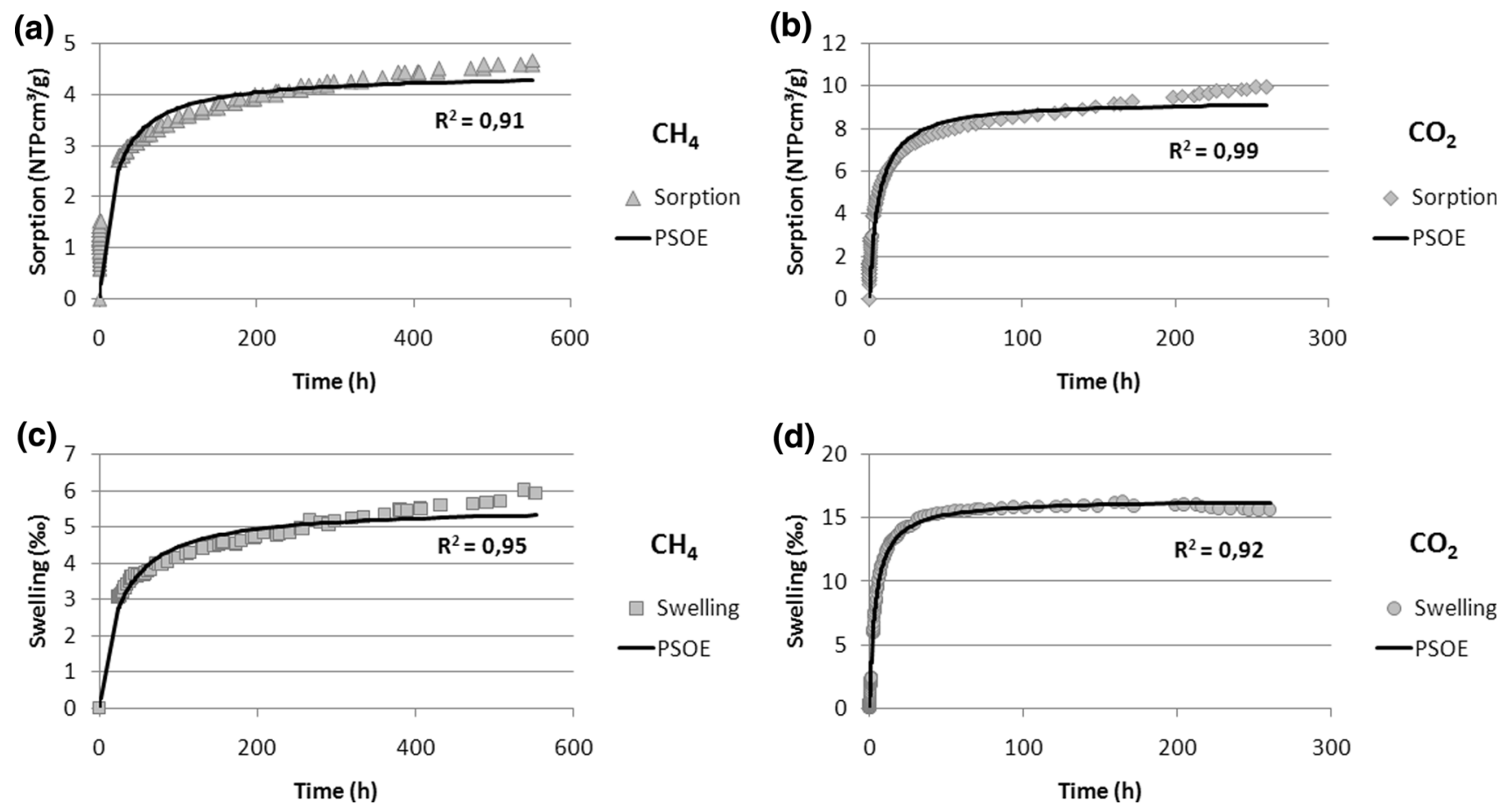

Fig. 5 Application of the PSOEs to the kinetics for $\mathbf{a} \mathrm{CH}_{4}$ and $\mathbf{b} \mathrm{CO}_{2}$ sorption (Eq. 7), and the sorption-induced coal swelling kinetics for c $\mathrm{CH}_{4}$ and $\mathbf{d} \mathrm{CO}_{2}$ (Eq. 8). The experimental data are given symbols: triangle for $\mathrm{CH}_{4}$ sorption, diamond for $\mathrm{CO}_{2}$ sorption, square for $\mathrm{CH}_{4}$ -

sorption-induced swelling, and circle for $\mathrm{CO}_{2}$-sorption-induced swelling. The solid line corresponds to the results of PSOEs application
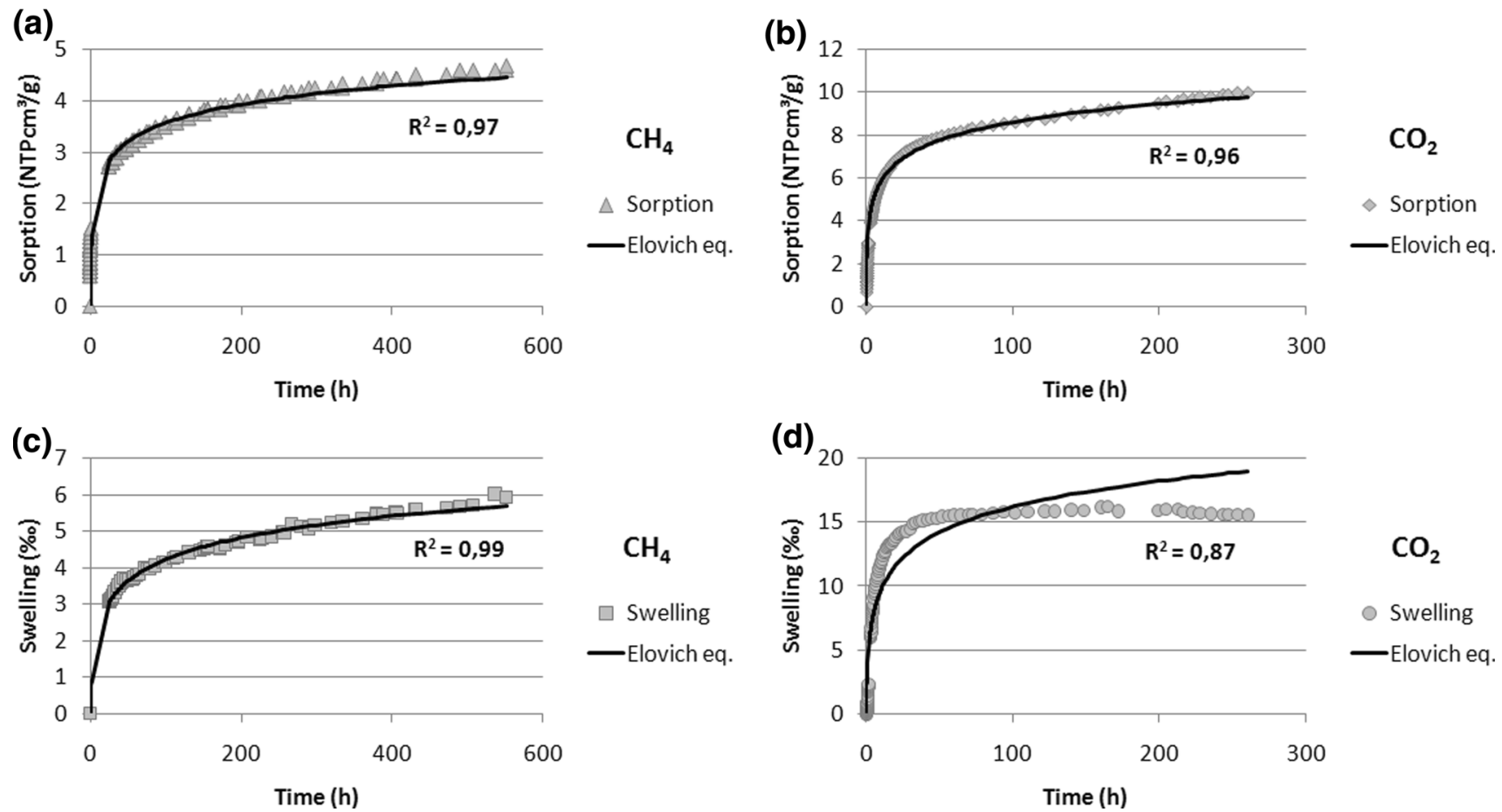

Fig. 6 Application of the Elovitch equations to the kinetics for $\mathbf{a} \mathrm{CH}_{4}$ and $\mathbf{b ~} \mathrm{CO}_{2}$ sorption (Eq. 9), and the sorption-induced coal swelling kinetics for $\mathbf{c} \mathrm{CH}_{4}$ and $\mathbf{d} \mathrm{CO}_{2}$ (Eq. 10). The experimental data are given symbols: triangle for $\mathrm{CH}_{4}$ sorption, diamond for $\mathrm{CO}_{2}$ sorption,

square for $\mathrm{CH}_{4}$-sorption-induced swelling, and circle for $\mathrm{CO}_{2}$ sorption-induced swelling. The solid line corresponds to the results of Elovitch equation application 

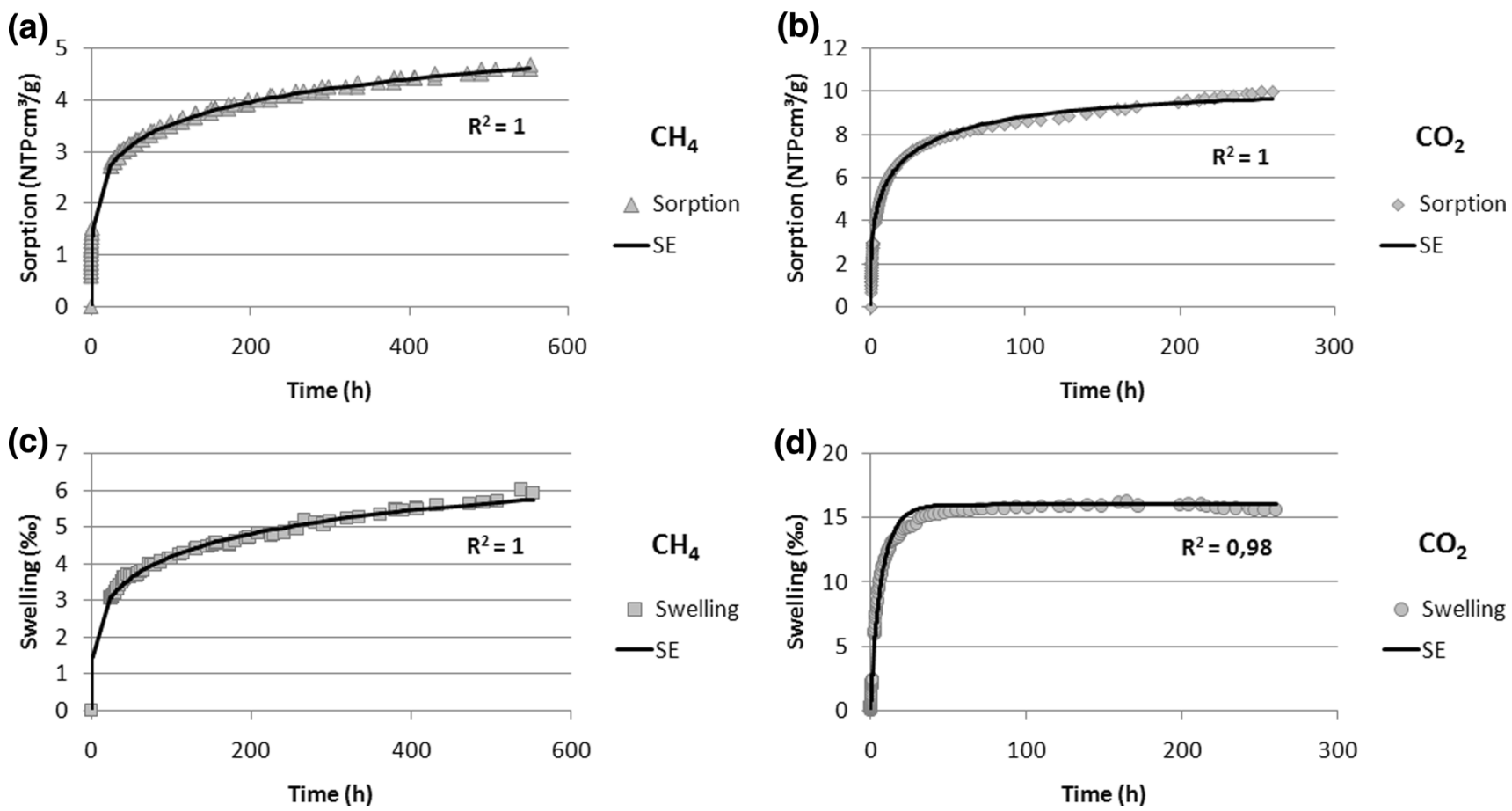

Fig. 7 Application of the SE equations to the kinetics for $\mathbf{a} \mathrm{CH}_{4}$ and b $\mathrm{CO}_{2}$ sorption (Eq. 11), and the sorption-induced coal swelling kinetics for $\mathbf{c} \mathrm{CH}_{4}$ and $\mathbf{d} \mathrm{CO}_{2}$ (Eq. 12). The experimental data are given symbols: triangle for $\mathrm{CH}_{4}$ sorption, diamond for $\mathrm{CO}_{2}$ sorption,

approach to fit the experimental results of both the sorption processes and expansion phenomena of solid coal samples.

\section{Conclusions}

In this study, five approaches were used to fit experimental sorption and dilatometric data of gas sorption to coal. For two equations based on the bidisperse gas transport model, the equation proposed by Busch et al. (2004) is better to interpret and quantify observed gas uptake rates in coal than the equation proposed by Siemons et al. (2007). The PSOE of Marecka and Mianowski (1993) is unsuitable for the data. The Elovich equation fits the results obtained in this study well, because the sorption and sorption-induced expansion processes were still in progress and the problem of a lack of a maximum sorbed amount value in the equation did not occur. However, because the function goes to infinity it should be avoided. The SE equation gives the best fit and is in very good agreement with the experimental results.

We believe that four out of the five equations investigated in this study are suitable to fit the kinetic curves of the accumulation of methane and carbon dioxide in the porous structure of coal and the kinetic curves of coal expansion that accompany the sorption processes. The

square for $\mathrm{CH}_{4}$-sorption-induced swelling, and circle for $\mathrm{CO}_{2}$ sorption-induced swelling. The solid line corresponds to the results of SE equation application

exceptions are the PSOE equation and the Elovitch equation to fit $\mathrm{CO}_{2}$-sorption-induced swelling of coal. The best fit to the experimental data was achieved using the SE equation.

Acknowledgments Financial support for this study was provided by the AGH University of Science and Technology (Framework No. 11.11.210.244).

Open Access This article is distributed under the terms of the Creative Commons Attribution 4.0 International License (http://crea tivecommons.org/licenses/by/4.0/), which permits unrestricted use, distribution, and reproduction in any medium, provided you give appropriate credit to the original author(s) and the source, provide a link to the Creative Commons license, and indicate if changes were made.

\section{References}

Aharoni, C., Tompkins, F.C.: Rates of adsorption of hydrogen, carbon monoxide and their mixtures on zinc oxide. Trans. Faraday Soc. 66, 434-444 (1970)

Aharoni, C., Suzin, Y.: Application of the elovich equation to the kinetics of occlusion. J. Chem. Soc. Faraday Trans. 1(78), 2321-2327 (1982)

Avrami, M.: Kinetics of phase change. I. General theory. J. Chem. Phys. 7, 1103-1112 (1939)

Busch, A., Gensterblum, Y., Krooss, B.M., Littke, R.: Methane and carbon dioxide adsorption/diffusion experiments on coal: an 
upscaling- and modeling approach. Int. J. Coal Geol. 60, 151-168 (2004)

Busch, A., Gensterblum, Y.: $\mathrm{CBM}$ and $\mathrm{CO}_{2}-\mathrm{ECBM}$ related sorption processes in coal: a review. Int. J. Coal Geol. 87, 49-71 (2011)

Baran, P., Zarębska, K., Bukowska, M.: Expansion of hard coal accompanying the sorption of methane and carbon dioxide in isothermal and non-isothermal processes. Energy Fuels 29, 1899-1904 (2015)

Blanchard, G., Maunaye, M., Martin, G.: Removal of heavy metals from waters by means of natural zeolites. Water Res. 18(12), 1501-1507 (1984)

Brouers, F., Sotolongo-Costa, O.: Generalized fractal kinetics in complex systems (application to biophysics and biotechnology). Phys. A 368, 165-175 (2006)

Bustin, R.M., Cui, X., Chikatamarla, L.: Impacts of volumetric strain on $\mathrm{CO}_{2}$ sequestration in coals and enhanced $\mathrm{CH}_{4}$ recovery. AAPG Bull. 92, 15-29 (2008)

Ceglarska-Stefańska, G., Majewska, Z., Majewski, S., Ziętek, J., Czerw, K.: Development of strain of coal subjected to sorptiondesorption processes. Gospod. Surowcami Min. 23, 41-50 (2007)

Charrière, D., Pokryszka, Z., Behra, P.: Effect of pressure and temperature on diffusion of $\mathrm{CO}_{2}$ and $\mathrm{CH}_{4}$ into coal from the Lorraine basin (France). Int. J. Coal Geol. 81, 373-380 (2010)

Chikatamarla, L., Cui, X., Bustin, R.M.: Implications of volumetric swelling/shrinkage of coal in sequestration of acid gases. In: Proceedings of the international coalbed methane symposium, Tuscaloosa, Alabama. paper 0435 (2004)

Clarkson, C.R., Bustin, R.M.: The effect of pore structure and gas pressure upon the transport properties of coal: a laboratory and modeling study: 1, Isotherms and pore volume distributions. Fuel 78, 1333-1344 (1999a)

Clarkson, C.R., Bustin, R.M.: The effect of pore structure and gas pressure upon the transport properties of coal: a laboratory and modeling study: 2, Adsorption rate modeling. Fuel 78, 1345-1362 (1999b)

Cui, X., Bustin, M.R., Chikatamarla, L.: Adsorption-induced coal swelling and stress: implications for methane production and acid gas sequestration into coal seams. J. Geophys. Res. 112, B10202 (2007)

Cui, X., Bustin, M.C., Dipple, G.: Selective transport of $\mathrm{CO}_{2}, \mathrm{CH}_{4}$ and $\mathrm{N}_{2}$ on coals: insight from modeling of experimental gas adsorption data. Fuel 83, 293-303 (2004)

Czerw, K.: Methane and carbon dioxide sorption/desorption on bituminous coal-experiments on cubicoid sample cut from the primal coal lump. Int. J. Coal Geol. 85, 72-77 (2011)

Czerw, K., Ziętek, J., Wagner, M.: Methane sorption on bituminous coal-experiments on cuboid-shaped samples cut from primal coal lumps. Gospod. Surowcami Min. 26, 85-96 (2010)

Dutka, B., Kudasik, M., Pokryszka, Z., Skoczylas, N., Topolnicki, J., Wierzbicki, M.: Balance of $\mathrm{CO}_{2} / \mathrm{CH}_{4}$ exchange sorption in a coal briquette. Fuel Process. Technol. 106, 95-101 (2013)

Gawor, M., Skoczylas, N.: Sorption rate of carbon dioxide on coal. Transp. Porous Media 101, 269-279 (2014)

Harpalani, S., Chen, G.: Estimation of changes in fracture porosity of coal with gas emission. Fuel 74, 1491-1498 (1995)

Jodłowski, G.S., Baran, P., Wójcik, M., Nodzeński, A., Porada, S., Milewska-Duda, J.: Sorption of methane and carbon dioxide mixtures in Polish hard coals considered in terms of adsorptionabsorption model. Appl. Surf. Sci. 253, 5732-5735 (2007)

Jodłowski, G.S.: The analysis of carbon dioxide sorption in the sequestration point of view. Gospod. Surowcami Min. 24, 139-148 (2008)

Kaszuba, J.P., Janecky, D.R.: Geochemical impacts of sequestering carbon dioxide in brine formations. In: Sundquist, E., McPherson, B. (eds.) Carbon Sequestration and its role in the global carbon cycle, geophysical monograph, vol. 183. American Geophysical Union, Washington, DC (2013)

Levine, J.R.: Model study of influence of matrix shrinkage on absolute permeability of coal bed reservoirs. In: Gayer, R., Harris, I. (eds.) Coalbed methane and coal geology, vol. 109, pp. 197-212. Geological Society Special Publication, London (1996)

Majewska, Z., Ceglarska-Stefańska, G., Majewski, S., Ziętek, J.: Binary gas sorption/desorption experiments on bituminous C coal: Simultaneous measurements of sorption kinetics, volumetric strain and acoustic emission. Int. J. Coal Geol. 77, 90-102 (2009)

Marczewski, A.W., Derylo-Marczewska, A., Słota, A.: Adsorption and desorption kinetics of benzene derivatives on mesoporous carbons. Adsorption 19, 391-406 (2013)

Marecka, A., Mianowski, A.: Kinetics of $\mathrm{CO}_{2}$ and $\mathrm{CH}_{4}$ sorption on high rank coal at ambient temperatures. Fuel 77, 1691-1696 (1993)

Mastalerz, M., Gluskoter, H., Rupp, J.: Carbon dioxide and methane sorption in high volatile bituminous coals from Indiana, USA. Int. J. Coal Geol. 60, 43-55 (2004)

Ottinger, S., Pini, R., Storti, G., Mazzotti, M.: Competitive adsorption equilibria of $\mathrm{CO}_{2}$ and $\mathrm{CH}_{4}$ on a dry coal. Adsorption 14, 539-556 (2008)

Pan, Z., Connell, L.D.: A theoretical model for gas adsorptioninduced coal swelling. Int. J. Coal Geol. 69, 243-252 (2007)

Pan, Z., Connell, L.D., Camilleri, M., Connelly, L.: Effects of matrix moisture on gas diffusion and flow in coal. Fuel 89, 3207-3217 (2010)

Płaziński, W., Dziuba, J., Rudziński, W.: Modeling of sorption kinetics: the pseudo-second order equation and the sorbate intraparticle diffusivity. Adsorption 19, 1055-1064 (2013)

Pone, J.D.N., Halleck, P.M., Mathews, J.P.: Sorption capacity and sorption kinetic measurements of $\mathrm{CO}_{2}$ and $\mathrm{CH}_{4}$ in confined and unconfined bituminous coal. Energy Fuels 23, 4688-4695 (2009)

Robertson, E.P., Christiansen, R.L.: Measurements of sorption-induced strain. Presented at the 2005 International Coalbed Methane Symposium, Tuscaloosa, Alabama, 17-19 May, Paper 0532 (2005)

Ruckenstein, E., Vaidyanathan, S., Youngquist, G.R.: Sorption by solids with bidisperse pore structure. Chem. Eng. Science 26, 1305-1318 (1971)

Seewald, H., Klein, J.: Methansorption an Steinkohle und Kennzeichnung der Porenstruktur. Glückauf-Forschungshefte 47(3), 149-156 (1986)

Shi, J.Q., Durucan, S.: Gas storage and flow in coalbed reservoirs: implementation of a bidisperse pore model for gas diffusion in coal matrix. SPE 84342, 1-9 (2003a)

Shi, J.Q., Durucan, S.: A bidispere pre diffusion model for methane displacement desorption in coal by $\mathrm{CO}_{2}$ injection. Fuel 82, 1219-1229 (2003b)

Siemons, N., Wolf, K.-H.A.A., Bruining, J.: Interpretation of carbon dioxide diffusion behavior in coals Int. J. Coal Geol. 72, 315-324 (2007)

George, J.D.S., Barakat, M.A.: The change of effective stress associated with shrinkage from gas desorption in coal. Int. J. Coal Geol. 69, 83-115 (2001)

Wdowin, M., Tarkowski, R., Franus, W.: Supplementary studies of textural and mineralogical changes in reservoir and cap rocks from selected potential sites suitable for underground $\mathrm{CO}_{2}$ storage. Arab. J. Sci. Eng. 39, 295-309 (2014a)

IWdowin, M., Tarkowski, R., Franus, W.: Determination of changes in the reservoir and cap rocks of the Chabowo Anticline caused by $\mathrm{CO}_{2}$-brine-rock interactions. Int. J. Coal Geol. 130, 79-88 (2014b)

Yi, J., Akkutlu, I.Y., Deutsch, C.V.: Gas transport in bidisperse coal particles: investigation for an effective diffusion coefficient in coalbeds. J. Can. Petrol. Technol. 47, 20-26 (2008)

Zarębska, K., Ceglarska-Stefańska, G.: The change in effective stress associated with swelling during carbon dioxide sequestration on natural gas recovery. Int. J. Coal Geol. 74, 167-174 (2008) 